Paedagogia Christiana

I/29 (2012) - ISSN 1505-6872

Jarostaw Michalski*

Toruń

\title{
Kształcenie ogólne czy specjalistyczne? A może jedno i drugie...
}

Dwa nurty w myśleniu: teoretyczny i praktyczny, tak wyraźnie widoczne w rozejściu się myślenia platońskiego i arystotelesowskiego, na zawsze pozostały w ludzkiej kulturze, a także w tym narzędziu jej zachowywania i przekazywania, którym jest edukacja. W historii różnie oceniano ich doniosłość. Bywały okresy, na przykład średniowiecze, w których niepodważalny był prymat wiedzy teoretycznej, uznawanej za niezbędny warunek wszelkiej spekulacji i dokonywania rozstrzygnięć praktycznych. W innych epokach z kolei, na przykład w oświeceniu czy pozytywizmie, znacznie większą wagę przykładano do praktycznej strony życia, a w edukacji promowano metodę poglądową i empiryzm. O ile jednak można powiedzieć, że tak jak na znanym fresku Szkoła Ateńska Rafaela wyczuwamy ducha jedności: spokojny dialog filozofów wskazuje, że teoretyczne i spekulatywne zainteresowania Platona i bardziej praktyczne podejście do filozofii, reprezentowane przez Arystotelesa, stanowią całość, która poddaje się duchowi racjonalności, o tyle w dziejach obserwujemy stopniowe rozchodzenie się tych dwóch nurtów myślenia, a w czasach obecnych wręcz przeciwstawianie ich sobie. Zjawisko to w sposób szczególny obserwujemy w ewolucji filozofii edukacji, która w coraz mniejszym stopniu postrzegana bywa jako przekazywanie kultury i formowanie szeroko pojętej sfery duchowej w człowieku. W dzisiejszych

* Ks. prof. dr hab. Jarosław Michalski jest kierownikiem Pracowni Pedagogiki Filozoficznej i Chrześcijańskiej na Wydziale Nauk Pedagogicznych UMK w Toruniu; od 2012 r. pełni funkcję prodziekana ds. naukowych na tym wydziale. Od 2012 r. jest redaktorem naczelnym „Paedagogia Christiana”. 
czasach nasila się bowiem w filozofii edukacji tendencja, aby wiedzę traktować instrumentalnie, jako narzędzie służące wyłącznie celom praktycznym, samo w sobie nieprzedstawiające żadnej wartości. Wiedza, której nie można „zastosować” w życiu, zazwyczaj określana nieco pogardliwie jako teoria, uważana jest za niepotrzebną, a młodych ludzi coraz częściej naucza się, że poznanie nie jest w swej istocie bezinteresowne i powinno zawsze łączyć się $\mathrm{z}$ realizacją jakiegoś praktycznego celu.

Wydaje się, że nie ma w dzisiejszym myśleniu o edukacji miejsca dla antycznego pojęcia paidei. W starożytnej Grecji paideia oznaczała formowanie człowieka, ze wskazaniem na jedność takich aspektów, jak cywilizacja, kultura, tradycja, literatura i wychowanie. Wychowanie traktowane było przy tym nie jako jedynie formalne umiejętności czy abstrakcyjna teoria, ale jako wewnętrzny i niezbywalny element rozwoju sfery duchowej człowieka. Za najcenniejszy element kultury i wychowania starożytni uważali literaturę, sądzili bowiem, że to w niej zarówno umiejętności, jak i teoria znajdują swój najpełniejszy wyraz ${ }^{1}$. Ten problem - konieczności wzajemnych zależności między kształceniem ogólnym a kształceniem specjalistycznym - stanowi główny cel niniejszego artykułu.

Chcąc odpowiedzialnie mówić o tym problemie, należy przede wszystkim pochylić się nad kategorią ,masy” w procesie edukacyjnym. Masa jako kategoria dyskursu w naukach społecznych ma bez wątpienia konotacje przede wszystkim etyczno-estetyczne. Od czasów Platona naznaczonych tęsknotą do wzniosłości rodzi w nas pewnego rodzaju dysonans między pięknem a szpetotą, między idealnym dobrem a prymitywizmem moralnym. Masa i masowość przywołuje bowiem myśl o intelektualnej i duchowej jałowości, braku tożsamości i upośledzonej kondycji człowieka. Dlatego być może, przynajmniej od czasów Oswalda Spenglera, intelektualiści obawiają się mas. Przeraża ich wizja dostarczona przez Jose Ortegę y Gasseta, ukazującego nieokiełznaną masę, zbuntowaną wobec wartości w roli źródła społecznej destrukcji². Wzbudza grozę „klasyczny” obraz G. Le Bona, opisującego thum rządzony zwierzęcym instynktem i ślepym afektem a stymulowany poczuciem własnej mocy ${ }^{3}$. Niezmiennie rodzą obawy analizy dokonywane przez Hannah Arendt, przedstawiające motłoch „odpad” burżuazyjnego społeczeństwa w roli siły napędowej totalitaryzmu, zaś masę, jako jego siłę sprawczą ${ }^{4}$.

${ }^{1}$ Zob. A. Męczkowska, Podmiot i pedagogika. Od oświeceniowej utopii ku pokrytycznej dekonstrukcji, Wrocław 2006.

2 Zob. J. Ortega y Gasset, Bunt mas, Warszawa 2006.

${ }^{3}$ Zob. G. Le Bon, Psychologia ttumu, Warszawa 1986.

${ }^{4}$ Zob. H. Arendt, Korzenie totalitaryzmu, Warszawa 2008. 
Niekiedy jednak przedstawia się masę w roli ofiary. Tak ma się rzecz $\mathrm{w}$ dialektyce oświecenia uznającej masowość za produkt rzekomego postępu dziejów oświetlanego ,słońcem kalkulującego Rozumu”. Nieco w podobnym tonie na temat masy pisze Baudrillard, wspominając o ludziach poświęcających swoje życie na rzecz funkcjonalnego istnienia. W kategoriach ofiary masę postrzega także Michale J. Oakeshott, uznając ją za ,,produkt uboczny” wyłonienia się nowożytnego państwa europejskiego, w wyniku czego część jednostek słabych, niezdolnych do udźwignięcia brzemienia politycznego sprawstwa, wydziedziczona $\mathrm{z}$ bezpiecznego świata feudalnych zależności, stała się ofiarą narzuconej wolności ${ }^{6}$. Niemniej, odchodząc od retoryki ofiary, podkreślmy, że gros myśli poświęconych zjawisku masowości traktuje ją jako wytwór określonych, historycznie osadzonych praktyk społeczno-ekonomicznych i towarzyszących im konsekwencji dla charakteru międzyludzkiej więzi.

Niewiele jest jednak prac, w których przedstawia się masę jako efekt (ofiarę?) oddziaływań edukacyjnych, mimo że w dyskusjach nad zjawiskiem masowości wyraźnie daje o sobie znać pedagogiczny wątek dotyczący jej związku z elementarnym brakiem myślenia umasowionych indywiduów myślenia wątpiącego, kwestionującego, a zarazem odpowiedzialnego, co w terminach Arendt - rozumiem jako myślenie 'we własnym imieniu' połączone z odwagą wydawania sądów.

Spróbuję zatem podjąć się próby bliższego rozważenia kategorii masy w odniesieniu do problematyki wychowania. Uczynię to, wypunktowując podstawowe zagrożenia dla edukacji związane z wychowaniem do masy.

\section{Zagrożenie pierwsze: Masa jako efekt postęu cywilizacyjnego}

Masa jako produkt ustanowienia porządku publicznego i chęci usunięcia z ludzkiego doświadczenia wizji przerażającej nędzy czy wykluczenia (każdy chce być piękny, zdrowy, a nader wszystko bogaty, nadania światu przejrzystości, a ludziom poczucia bezpieczeństwa7 ${ }^{7}$. Odczuwszy swoją siłę, osiągnąwszy względny komfort życia i poczucie bezpieczeństwa - masa odczuwa samowystarczalność: nie potrzeba jej elit, bogów, drogowskazów. Człowiek umasowiony jest dla siebie jedynym punktem odniesienia i czuje się z tym dobrze. Zbędne są dla niego wartości kultury wysokiej, obce mu

${ }^{5}$ M. Horkheimer, T. W. Adorno, Dzialektyka oświecenia, Warszawa 1994, s. 78.

${ }^{6}$ Zob. M. J. Oakeshott, O postepowaniu czlowieka, Warszawa 2008.

7 J. Michalski, Sens życia a pedagogika. Impulsy myśli Viktora E. Frankla, Toruń 2011, s. $57-74$. 
autorytety. Ufny w swoją moc, ,współczesny człowiek masowy jest faktycznie prymitywem, który bocznymi drzwiami wślizgnął się na starą i szacowną scenę cywilizacji”».

\section{Zagrożenie drugie: Spoleczeństwo masowe}

Społeczeństwo masowe, termin zbudowany w okresie modernizmu, to typ formacji społecznej, bezwiednie asymilującej wpływy homogenicznej kultury masowej, w którym następuje erozja tradycyjnych struktur, więzi i wartości, a aktywność ludzka sprowadza się do kolektywnej rytmiki nierefleksyjnych działań. O masowości tej formacji decyduje nie jej liczebność bądź określona jakość, lecz cała seria braków, do których zalicza się:

- brak społecznej podmiotowości, przejawiającej się brakiem zdolności do samostanowienia;

- osłabienie więzi społecznych i wycofanie zaangażowania. Społeczeństwo masowe jest $\mathrm{w}$ gruncie rzeczy zbiorowiskiem jednostek wyalienowanych;

- brak aspiracji, poczucia sensu i celu, odpowiedzialności i moralnego zobowiązania - masa pozbawiona jest moralnej integralności, w zamian mało efektywnej ,protezy" moralnego porządku dostarcza jej kultura masowa bądź ideologia';

- zanik zmysłu krytycznego, przejawiający się w odbiorze świata jako „Zastanej danej niezmiennej”;

- rozmyta (niekiedy uznawana za w ogóle nieobecną) forma tożsamości, która nie koncentruje się wokół wspólnych celów czy wartości ani też przynależności klasowej, etnicznej, religijnej;

- „ułomność” jednostek zrzeszonych w społeczeństwie masowym które łączy niezdolność do prowadzenia indywidualnego życia i tęsknota za „przytuliskiem jakiejś wspólnoty”; człowiek umasowiony jest istotą reaktywna w przeciwieństwie do człowieka aktywnego i racjonalnego;

- zastąpienie życia zracjonalizowanego społeczeństwa przez życie społeczne o dominancie empatycznej, co stanowi antytezę procesu wyłaniania się społeczeństw nowożytnych ${ }^{10}$.

Człowiek umasowiony jest $\mathrm{w}$ istocie swej istotą reaktywną $\mathrm{w}$ przeciwieństwie do człowieka aktywnego i racjonalnego, człowiekiem wiecznie

8 J. Ortega y Gasset, dz. cyt., s. 86.

9 J. Michalski, dz. cyt., s. 114-116.

${ }^{10}$ Por. J. Turowski, Wielkie struktury społeczne, Lublin 2000, rozdz. 11. 
tęskniącym do „przytuliska jakiejś wspólnoty” rozumianej organistycznie, a nie konstruktywistycznie.

\section{Zagrożenie trzecie: czlowiek bez właściwości}

Jednostkę „ucieleśniającą się” w masie postrzegać można w kategoriach zaprzeczenia podmiotowości. Jako „człowieka bez właściwości”, który uobecnia się jedynie poprzez „dostrajanie się” do aury zbiorowego doświadczenia bądź namiętności; który oddaje swoje ja nieustannie trwającej chwili; wykorzenionego ze źródeł, pozbawionego historii a przeto i przyszłości. Człowiek umasowiony jest przeciwwagą dla podmiotu heroicznego, będącego Panem samego siebie a zarazem Twórcą historii. Jest on zaledwie osobą mimetyczną „odgrywającą jakąś rolę na scenie życia, zmieniającą maski kostiumy i miejsca spektakli. Jest zaprzeczeniem podmiotowej substancjalności, antytezą nowożytnej indywidualizacji - apoteozy JA, wynoszącej suwerenność ludzkiego Cogito. Czytać człowieka bez właściwości jako osobę, to czytać ją jedynie w kategoriach retorycznych"11.

\section{Zagrożenie czwarte: grawitacyjny opór i (post)polityczna moc}

Dynamika funkcjonowania mas kształtowana jest przez przemożną siłę grawitacji. Masa zawsze bowiem ,ściąga w dół”. Wyzuta z aspiracji i ambicji, pragnie sprowadzić wszystkich i wszystko do swojego poziomu - poziomu przeciętności. Człowiek masowy sam czując się pospolitym, żąda, by pospolitość była prawem i odmawia uznania jakichkolwiek nadrzędnych wobec siebie instancji. Odmowa mas wobec wartości ,wyższego świata” - czy to ujmowanego w kategoriach humanistycznego dziedzictwa Grecji, Rzymu, Jerozolimy, czy też „swoiście ludzkiego” pragnienia sensu - przybiera formę oporu. Jest to opór czysto fizyczny, nie czerpiący z siły krytycznej refleksji a zawdzięczający swą moc sile bezwładu. Jest oporem przejawiającym się w milczeniu i hiperkonformizmie. Praktyki „oporu” wyrażanego przez masy mają charakter czysto „organiczny”. Ważna jest w istocie jakaś forma „społecznej więzi” przez nie wytwarzana, a nie to, ku czemu są one zwrócone. Jest to opór zwierzęcy - dający możliwość fizycznego przetrwania, opór bierny - a jednocześnie wskazujący na niepojętą moc życia bez właściwości, ukazujący witalizm mas. Opór wyzwala moc przetrwania - chodzi tu

11 Por. D. Wajsprych, Pedagogia agatologiczna. Studium hermeneutyczno-krytyczne projektu etycznego Józefa Tischnera, Olsztyn-Toruń 2011, s. 13-15. 
o moc, której nie należy mylić z władzą, chodzi o moc, która pozwala dostosować się do ograniczeń nie ulegając im całkowicie. Chodzi o to, by ludzkie zwierzę wciąż miało się dobrze ${ }^{12}$.

\section{Zagrożenie piąte: intelektualizm umasowiony}

Zagrożeniem tym rządzi zasada absolutnej równości. Równość ta nie jest równością w sensie politycznym, lecz ma fizyczny charakter zrównania: gustów, aspiracji, zachowań, etc ${ }^{13}$. Masowość zyskuje postać uniwersalną; posiada moc obejmowania wszystkich warstw i grup społecznych: czy to reprezentantów ekonomicznych i społecznych czy lumpenproletariatu; posiada moc organizowania społeczeństwa bez klas i podziałów. Popadać w intelektualizm umasowiony, to nic innego jak wypowiadać się językiem mas, powtarzać głupstwa, przejąć kłótliwość, powierzchowność myślenia, emocjonalną naturę $\mathrm{i}$ histeryczne reakcje ${ }^{14}$.

\section{Zagrożenie szóste: „wychowanie”, które nie łączy i nie rozdziela}

Jest to aporia nawiązująca do ducha krytycznej Szkoły Frankfurckiej, a mówiąca, że masowość jest wytworem konkretnych okoliczności społeczno-kulturowych, w tym - edukacji. Myślę tu o edukacji, która upośledza człowieka w dwóch wymiarach wskazanych przez Arendt: $\mathrm{z}$ jednej strony edukacji blokującej proces indywidualizacji; z drugiej - alienującej z międzyludzkich więzi.

Równolegle zachodzące procesy socjalizacji i indywidualizacji stanowią jedną z aporii procesu wychowania - procesu, w którym rozwój człowieka, prowadzący do osiągania zdolności samookreślenia, krytycznego - zdecentrowanego myślenia i wydawania sądów moralnych, zachodzi w kontekście społecznych interakcji i towarzyszy mu budowanie międzyludzkich więzi oraz zwiększające się poczucie odpowiedzialności za zamieszkiwany świat. Nie istnieje możliwość rozerwania tego związku, bo zarówno myślenie rozwija się w naturalnym środowisku międzyludzkiej komunikacji, dojrzewająca świadomość Ja potrzebuje jakiegoś My, do którego musi się odnieść, a same procesy socjalizacji mają refleksyjny, zapośredniczony w autonomii

12 Por. J. Baudrillard, W cieniu milczacej większości albo kres sfery społecznej, Warszawa 2006, s.124-126.

${ }^{13}$ H. Elzenberg, Wartość i czlowiek, Torun 2005, s. 175-184.

${ }^{14}$ Por. J. Ortega y Gasset, dz. cyt., 131 i n. 
podmiotu, nie zaś mechaniczny, charakter. Nie można zatem mówić o wychowaniu dobrym i udanym inaczej niż w kategoriach socjalizacyjnej indywidualizacji jako dialektycznego związku obydwu tych czynników.

Współczesne wychowanie i edukacja masowa - opierając się na założeniach emancypacyjnych, dążyć powinna do realizacji funkcji przygotowania wschodzącego pokolenia do społecznego i kulturowego uczestnictwa, przeciwstawiając się faktowi bierności mas ${ }^{15}$.

Dobrym podsumowaniem dotychczasowych analiz może być, jak są-

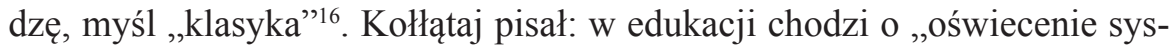
tematyczne",

które by roznieciło światło po całym kraju, lecz które by go nie obciążyło próżniackimi półmędrkami; aby, mówię, rolnik, rzemieślnik, wieśniak, mieszczanin, ubogi i bogaty znaleźli stosowne do swego losu oświecenie, bez podniety próżnego szperania w naukach wyższych nad swój stan, $[\ldots]$ im pomagając wznieść się tak wysoko, jak tylko możność ludzka pozwala.

Jej celem nie jest uzyskanie możliwie najwyższego wykształcenia, lecz poszerzanie obszaru kompetencji (intelektualnych, społecznych, etycznych), budowanie orientacji w świecie, zwiększanie możliwości życiowych i kształtowanie się poczucia tożsamości. Wychowanie jako spotkanie osób jest tego żywym potwierdzeniem.

Wydaje się więc - jak zaznaczono na wstępie - że nie ma w dzisiejszym myśleniu o edukacji miejsca dla antycznego pojęcia paidei, które w książce pod tym właśnie tytułem przybliżył współczesnemu czytelnikowi Werner Jaeger ${ }^{17}$. Podkreśla on, że w późniejszym rozwoju historycznym dzięki takiej właśnie formacji duchowej Hellada, ,straciwszy wszystko, co liczy się na tym świecie: państwo, potęgę, wolność i życie obywatelskie w klasycznym rozumieniu tego słowa, mogła mimo wszystko powiedzieć za swoim ostatnim wielkim poetą Menandrem „To, czego nikt nie można zabrać człowiekowi, to paideia $^{18}$. Ideał paidei, który ukształtował się w epoce klasycznej, miał bowiem tak wielką siłę, że odegrał decydującą rolę również w rozwoju późniejszej cywilizacji grecko-rzymskiej. Ukształtowane przez greckich geniuszy wychowania ,ideały kulturowe przetrwały niepodległy byt poli-

${ }^{15}$ H. Arendt, dz. cyt., s. 56.

${ }^{16}$ H. Kołłątaja Zasady wychowania publicznego, [w:] Stan oświecenia w Polsce w ostatnich latach panowania Augusta III (1750-1764), opr. J. Hulewicz, Wrocław 1953.

${ }_{17}$ Zob. W. Jaeger, Paideia, Warszawa 2001; tenże, Wczesne chrześcijaństwo i grecka paideia, Bydgoszcz 2002.

18 Tenże, Paideia, s. 10. 
tyczny narodu i przeszły w posiadanie innych ludów starożytnych oraz ich następców jako najdoskonalszy wyraz humanizmu" 19 .

Rozejście się dwóch nurtów poznania: teoretycznego i praktycznego, co obserwujemy w czasach współczesnych, jest - jak się wydaje - wyrazem tendencji odwrotnej w stosunku do zasady organicznej jedności i ciągłości, zgodnie z którą rozwijała się kultura grecka w swoim postrzeganiu świata jako całości. Można powiedzieć, że to właśnie dzięki jedności aspektu teoretycznego i praktycznego w myśli greckiej ówczesna filozofia, matematyka, muzyka i rzeźba stanowily swoistą jedność w różnorodności. Co więcej, spajający wszystkie te dziedziny ideał paidei sprawiał, że najwyższe zdobycze kultury na każdym etapie jej rozwoju wywierały wpływ na kolejne pokolenia, to zaś - niejako przez sprzężenie zwrotne - stymulowało jej harmonijny rozwój i ciągłość.

Warto przy tym pamiętać, że ideał greckiej paidei oparty był na przekonaniu, że ,przekazywanie kultury nie jest możliwe bez wyobrażenia sobie ideału człowieka, jakim być powinien, przy czym nieważny, a w każdym razie nieistotny, staje się wzgląd na praktyczny pożytek, natomiast miarodajne okazuje się to kalon, tj. piękno jako ideał zobowiązujący i pociągający do naśladowania"20. Kontynuację tej idei odnajdujemy w cywilizacji chrześcijańskiej, która przejąwszy najcenniejsze osiągnięcia doby antyku, wskazywała, że owym ideałem i wzorem zobowiązującym do naśladowania jest Chrystus, Syn Boży, a zarazem „,najpiękniejszy z ludzi” ${ }^{21}$. Już we wczesnym chrześcijaństwie wychowanie postrzegane było jako świadomie podejmowane pielęgnowanie ideału doskonałości ludzkiej, jako proces podobny do budowania, którego istotę dobrze oddaje niemieckie słowo Bildung, oznaczające zarazem kształtowanie i kształcenie. Chociaż kultura greckiego antyku - jak również kultura chrześcijańska w pierwszych okresach swojego rozwoju należała w zasadzie do warstw wyższych, jej istotnymi współczynnikami były racjonalizm i uniwersalizm, które predestynowały ją do tego, by stała się kulturą ogólnoludzką.

Jeśli kultura ma był „przywilejem” należnym „szlachetnemu urodzeniu”, to nie ma słuszniejszych uprawnień do tego przywileju niż te, które leżą w naturze człowieka jako stworzenia rozumnego. Dzięki temu zamiast doprowadzić do zwulgaryzowania tego, co było szlachetne w kulturze greckiej, potrafiła ona

19 Tamże.

20 Tamże, s. 48.

${ }^{21}$ J. Ratzinger, Zraniony strzała piękna. Krzyż i nowa ,estetyka” wiary, „Ethos” 1-2 (2004), s. 18. 
uszlachetnić cały rodzaj ludzki, dając mu program i wzór wyższej formy życia, życia zgodnego $\mathrm{z}$ rozumem ${ }^{22}$.

To właśnie z greckiego przekonania o godności człowieka, przekonania ubogaconego również późniejszymi wpływami rzymskimi, a przede wszystkim „rewolucją”, którą dla myślenia o człowieku stanowiło chrześcijaństwo, wyrosło pojęcie zindywidualizowanej osobowości, będące podstawą dzisiejszej psychologii i pedagogiki. Podkreślając godność i niepowtarzalną wartość każdej osoby ludzkiej, chrześcijaństwo podkreślało zarazem, że życie ludzkie na ziemi jest dążeniem ku ostatecznemu celowi człowieka - Bogu, a istotnym instrumentem tego dążenia, wyznaczającym zarazem jego całościowy kierunek, jak i konkretne drogi ludzkiego postępowania, jest poznanie. W słowach wypowiedzianych przez Chrystusa, ,najpiękniejszego z ludzi”: „I poznacie prawdę, a prawda was wyzwoli” (J 8, 32), odnajdujemy chrześcijańskie związanie z sobą teoretycznego i praktycznego aspektu ludzkiego poznania, kulminujące w poznaniu Boga.

Jak ukazuje historia, wraz z rozchodzeniem się nurty poznania teoretycznego i praktycznego - początki tego zjawiska odnaleźć można już w myśli renesansowej, a punkt zwrotny w teorii i praktyce społecznej doby oświecenia - w kulturze zarysowywać się zaczyna nowa koncepcja człowieka. Przestaje on być postrzegany jako przede wszystkim byt rozumny, byt, którego zasadniczym wyróżnikiem - obok jego niepowtarzalnej godności jest intelekt służący interioryzacji wiedzy i umożliwiający posługiwanie się nią za pomocą operacji logicznych, intuicji i empatii. W szeroko pojętej nowej koncepcji antropologicznej, którą chętnie przejmują współcześni metodolodzy nauczania poszczególnych przedmiotów szkolnych, człowiek jest postrzegany jako byt przede wszystkim emotywny, kierujący się tak w poznawaniu świata, jak i w postępowaniu emocjami, które są również pośrednikami w nabywaniu przez niego wiedzy (myśl ta jest szczególnie widoczna choćby w nowoczesnych koncepcjach metodycznych dotyczących nauczania języków). Nauczanie jest zatem rozumiane jako oddziaływanie zwłaszcza na sferę emocjonalna, mniej zaś na intelektualną. Obserwujemy w nim również odchodzenie od metod dedukcyjnych, które zastępowane są ćwiczeniem przez uczniów - już na najniższym poziomie kształcenia - umiejętności wnioskowania indukcyjnego, zdaniem teoretyków, przyczynia się ona bowiem do rozwoju samodzielności młodych ludzi i do tworzenia przez nich własnych uogólnień. Jednocześnie zdobywana w ten sposób wiedza przestaje służyć wyrażaniu myśli, interpretowaniu świata i uzasadnianiu przyjmowania określonych postaw życiowych (chociażby takich, jak wybór partii

${ }^{22}$ W. Jaeger, Paideia, s. 51. 
politycznej w wyborach), a staje się narzędziem pozwalającym sprawnie poruszać się w świecie, na poziomie życia praktycznego, bez konieczności czynienia wysiłku jego rozumienia. Można zaryzykować stwierdzenie, że w czasach współczesnych edukacja uległa spłaszczeniu: jej wymiar duchowy - tak mocno podkreślany przez Greków w pojęciu paidei i stanowiący następnie podstawę kultury chrześcijańskiej - uległ redukcji do wymiaru psychologicznego. Wydaje się, że dla wielu dzisiejszych teoretyków, decydujących tak o „obowiązującej” filozofii kształcenia, jak i o konkretnych wzorcach i metodach nauczania poszczególnych przedmiotów szkolnych, człowiek w pewnym sensie przestał być tajemnicą, a stał się bytem, który działa według określonych mechanizmów - przewidywalnych i możliwych do szczegółowego poznania. Być może dlatego w dzisiejszej polskiej (chociaż nie tylko polskiej) szkole tak niewiele jest miejsca dla wielkiej literatury, która - zdaniem Greków - ujawniła to, co w człowieku najgłębsze. Być może dlatego na lekcjach języków obcych uczniowie nie zdobywają już umiejętności wyrażania swoich myśli i poglądów ani rozumienia sensów językowych, ale ćwiczą, jak praktycznie poruszać się w świecie nieznanej im kultury, właściwie „reagować” na usłyszane wypowiedzi i „konstruować” wypowiedzi własne. Być może też dlatego na egzaminach pisemnych z języka polskiego sprawdzający nie ma możliwości docenienia twórczego charakteru pracy ucznia, gdyż ci, którzy układają testy, nie uważają tej cechy wypowiedzi za istotną dla całościowej oceny egzaminu.

Problem „nowej edukacji” dotyczy jednak nie tylko szerokiego filozoficzno-kulturowego tła, na jakim zachodzą obecne przemiany w myśleniu o wychowaniu, ale również całego szeregu kwestii znacznie częściej podnoszonych przez nauczycieli-praktyków, którzy zadanie edukacji i wychowania młodzieży realizują na co dzień w szkołach różnego stopnia. Pierwszą z nich jest już sam egalitaryzm, który wkroczył do instytucji edukacyjnych nie tylko w naszym kraju. Niegdyś elitarna i z tego względu wysoko ceniona edukacja - wraz z upowszechnieniem praw człowieka, w tym również prawa do wykształcenia - straciła obecnie swój uprzywilejowany w społeczeństwie charakter. W polskich warunkach widzimy, jak spada prestiż powszechnej edukacji jako takiej: ludzie nie cenią sobie tego, co zdobywają bez wysiłku, na co nie muszą zasłużyć ani zapracować (chociaż z drugiej strony cenione są umiejętności praktyczne, które można zdobyć w szkole i które ułatwiają znalezienie pracy). Szkoły są często miejscem ,uśrednienia” młodzieży (poziom nauczania rzadko dostosowywany bywa do uczniów lepszych), a nawet demoralizacji, co jest zjawiskiem szczególnie bolesnym w przypadku małych dzieci, które dopiero rozpoczynają naukę na poziomie podstawowym. Często zagubiona zostaje w szkole indywidualność poszczególnych uczniów, którzy stają się dla nauczycieli - niebędących w stanie poznać wszystkich 
swoich wychowanków - numerami w dzienniku lekcyjnym. Powstaje zatem nieco prowokacyjne pytanie, czy powszechny obowiązek szkolny rzeczywiście służy edukacji. $Z$ pytaniem tym łączy się inna kwestia: czy szkoły, od podstawowych poczynając, a na wyższych kończąc, oraz inne instytucje edukacyjne powinny pozostawać własnością państwa? Czy - z drugiej strony - całkowicie prywatne szkolnictwo oznaczałoby, że w szkołach zaniknie element wychowawczy, a staną się one usługowymi instytucjami kształceniowymi, które działają kierowane wyłącznie prawami rynku?

Jak na tym tle oceniać wprowadzaną wcześniej i aktualnie (można powiedzieć ciągle) w Polsce reformę edukacji? Zmierza ona bowiem nie tylko do upowszechnienia obowiązku szkolnego na poziomie podstawowym, ale do zwiększenia liczby obywateli legitymujących się wykształceniem średnim i wyższym, a to dzieje się najczęściej kosztem uśrednienia poziomu nauczania i zaniedbania zdolności uczniów najlepszych ${ }^{23}$.

Wydaje się, że przesłanie płynące z powyższych analiz streszczają najlepiej słowa, które wypowiedział w rozmowie z Patrycją Mikulską długoletni lubelski wychowawca młodzieży Michał Bobrzyński: „Szkoła ma wychowywać poprzez rzetelne uczenie. Szkoła dobrze wypełnia swoją funkcję wychowawczą, gdy solidnie uczy, gdy wymaga spełnienia obowiązku, a to zakłada i rzetelność i uczciwość - czyli wychowanie". Słowa te wskazują dziś na potrzebę powrotu do paidei, która - jak przypomina Jaeger, cytując Menandra - ,jest portem schronienia dla każdego człowieka"24. Być może odzyskanie tej idei pozwoliłoby również myślicielom naszego czasu umieścić się w ponadczasowej harmonijnej wspólnocie miłośników mądrości, tak przekonująco sportretowanej przez Rafaela w jego pięknym fresku.

\section{General or Specialised Education? Or Maybe Both... (Summary)}

Two trends in thinking: a theoretical and a practical one, so evident in differences between Platonic and Aristotelian thinking, have forever remained in human culture and in education, which is a tool for preservation and transmission of culture. Their significance was evaluated differently in the past. There were times, for instance during the Middle Ages, when theoretical knowledge was definitely more important and was considered a necessary condition for any reasoning or practical decision making. In other periods of history, however, for example during the Enlightment or Positivism, much more attention was given to the practical aspect of life, and

${ }^{23}$ Zob. B. Przyborowska, Pedagogika innowacyjności, Torun 2013.

${ }^{24}$ W. Jaeger, Paideia, s. 10. 
sensory experience as well as empirical evidence was promoted within the area of education. However, while on the one hand it can be said that on Raphael's famous fresco The School of Athens a spirit of unity can be sensed - the peaceful dialogue between philosophers indicates that theoretical and speculative interests of Plato and the more practical approach towards philosophy represented by Aristotle make a whole which surrenders to the spirit of rationality - on the other hand, it can be seen that over the centuries these two trends of thinking grew apart, and currently are in opposition. This phenomenon is evident especially in the evolution of the philosophy of education, which is considered less and less as transmission of culture and formation of broadly understood spiritual sphere of man. These days there is a growing tendency in the philosophy of education to treat knowledge instrumentally, as a tool that serves only practical purposes and does not have any value itself. Knowledge that cannot be applied practically in life, usually rather contemptuously referred to as theory, is considered to be unnecessary and young people are taught more and more often that cognition is not selfless and should always be linked to achieving some practical goals.

It appears that in the contemporary thinking about education there is no place for the ancient concept of Paideia. In ancient Greece, Paideia referred to education process that combined such aspects of life as civilisation, culture, tradition, literature and moral refinement. Education was seen not only as teaching merely formal skills or abstract theory, but also as focusing on the development of the inner, spiritual realm of human existence. Literature was considered the most valuable element of culture and education because the ancient thinkers believed that both skills and theory find their fullest expression in this discipline. This issue - the necessity for interdependence between general education and specialised training - is the main focus of this article. 